\title{
Farming System and Food Security in Western Sudan: Are the Things Improving?
}

\author{
Samar M. Abdalla1* ${ }^{*}$ Eltighani Elamin ${ }^{2}$ \\ Agricultural Research Corporation (ARC), Agricultural Economics and Policy Research Centre (AEPRC), \\ Khartoum, Sudan \\ Email: $\underline{\text { Samar-122@hotmail.com }}$
}

Received 14 January 2015; accepted 30 January 2015; published 3 February 2015

Copyright (C) 2015 by authors and OALib.

This work is licensed under the Creative Commons Attribution International License (CC BY). http://creativecommons.org/licenses/by/4.0/

(c) (i) Open Access

\section{Abstract}

This paper seeks to describe the farming system and food security as well as the activities against food insecurity in western Sudan. The secondary data on farming system and food security were collected from ministry of agriculture, ministry of health, WFP and FAO, as well as other relevant sources. Descriptive statistics analysis was used to analyze the data. The finding shows that the cultivated areas under cash crops are increased over the time compared with food crops. This is mainly resulted from some policy transformation and structure changes that seek to expand the area under cash crops. Alternatively, food security is influenced by low productivity and unclear marketing price policies for agricultural products as well as inequality and lack of income. Moreover, two programs were implemented to alleviate the food insecurity problems, namely, school feeding program (SFP) and food for work (FFW). However, the lack of food diversification and poor transportation are the negative factors affecting the stability of SFP. Consequently, adopting the improved technologies through strong and powerful research institutions and extension services will enhance the farming system and food security as well. Additionally, the SFP and FFW should provide diversified foods that are nutritional based rather than caloric based for the vulnerable people.

\section{Keywords}

Farming System, Food Insecurity, Food Crops, Cash Crops, School Feeding Program, Food for Work Subject Areas: Agricultural Science, Food Science \& Technology

\section{Introduction}

Sudan is one of the Sub-Saharan African (SSA) countries suffering from severe problems of food insecurity ${ }^{*}$ Corresponding author. 
among its population during the last decades. Oil production and exports have a positive impact on the economic growth and development. However, $50 \%$ to $60 \%$ of the population is suffering from poverty and food insecurity with a high variation among the regions [1]. This condition is attributed to two specific reasons. The first reason is the drastically declining in the role of agricultural sector, which supports the livelihood of $80 \%$ of the population. The second reason is that the increase in the economic growth and benefits from oil exports do not trickle down to the poor. In fact, Sudan has lost its self-sufficiency from cereal food grains due to the serious drought, desertification, civil war crises and inappropriate government policies.

Western Sudan is known as a vast semi-arid region and occupies the largest economic area in Sudan. It covers about $57 \%$ of the total cultivated land of Sudan. Western Sudan occupies $85 \%$ of the annual cultivation area and plays a significant role in supporting the livelihood for more than $70 \%$ of the population. The traditional region of western Sudan supports the agricultural market and hence contributes extensively to the export of crops; this is estimated at about $60 \%$ of the country's foreign exchange earnings as argued by [2]. However, during the last decades the traditional region of western Sudan has experienced huge variations in the environmental conditions. Drought, desertification and instability of rainfall are the major environmental troubles in this region. These symptoms are interrelated with each other and they have a major influence and effect on the economic activities, crop production and food security.

Desertification happens actually due to low soil fertility, high population pressure and high variations in the climatic conditions, combined with unsustainable and extensive usage of land and natural resources [3]. The most consequence of the long process of both drought and desertification is the famine. Famine spread widely during the last decade, particularly in the period 1984-1985. The negative impact of drought and desertification is apparent in the deterioration of economic growth, higher poverty rate, low agriculture production, water shortage, lack of biodiversity, low income, poor health, low sanitary conditions and inadequate food intake, as well as rural-urban migration [4]. Additionally, western Sudan is distinguished by higher fluctuations and instability in the rainfall, which obliviously affects the annual crops cultivation.

The western Sudan exhibits similar conditions concerning the common features of crop production and food insecurity in Sudan. The majority of people in this region are occupied with agriculture and related activities. In addition to gum Arabic taping and pastoral activities, they cultivate food crops (sorghum and millet) and cash crops (sesame, groundnut, hibiscus and watermelon). The fluctuations of rainfall and desertification (discrepancy of the desert) combined by widespread crop diseases have led to difficult management of field crops [5]. Recently, the western Sudan has suffered from low crops productivity [2]. Consequently, rural people have suffered from continuous deterioration in their food availability and food consumption as well. This creates a higher food deficit in this region.

Currently, this situation is aggravated by some policy transformation and structure changes adopted by the government. These policies encourage the transformation of the crop production system from subsistence to commercial cropping patterns. Thus, the majority of the farmers have changed their production from food crops to cash crops. Consequently, the people are distressed by higher food deficiency due to the low quantities of food produced. Nowadays, the per capita income from crop production has fallen below the poverty line [6]. The low crop production turned into low quantity of cereal foods saved for home subsistence. Subsequently, the outcome of the low agricultural production and the reduction in the farm income tied with a rapid rise in food prices had obligated the people to adopt various coping strategies in order to mitigate the food shortage. Additionally, the internally displaced persons (IDPs) have also destroyed and demolished the economic activities and have led to a prevalence of human and food poverty. Such a situation causes widespread diseases, malnutrition and poor sanitary conditions. Subsequently, this situation leads to unavailability of food, inaccessibility to enough food and/or bad quality of food consumption.

Recently, the consumption of cereal foods contributes more than $54 \%$ to the total daily per capita caloric intake. The consumption of rural people is characterized by low food diversity, which results in a high prevalence of malnutrition and low caloric intake. The per capita caloric intake is below the FAO minimum energy requirements $(2100 \mathrm{kcal})$. In agreement with this, the average per capita energy intake for the rural people is about 1663 $\mathrm{kcal}$ and for the North Kordofan State is about $1803 \mathrm{kcal}$ which is very low [7]. Western Sudan is suffered from an inadequate condition of food security and livelihood system thereby; this region is known as vulnerable and food deficit area.

Accordingly, many efforts have been conducted by the government of Sudan and non-governmental organizations (NGOs) to reduce the consequences of food insecurity; however, there is little improvement. One of the 
most significant reasons for this is a lack of good coordination between the government and the international donors.

\section{Research Objectives}

In Sudan, various studies have positively contributed to the farming system, food consumption and food security. However, the continuous deterioration of the farming system, low crop production and inadequate food consumption are required further investigation. Thus, the main objective of this study is to assess the situation of the farming system as well as food security in the western Sudan. More specifically this research aims to:

1) Assess the general characteristics of the farming system (crop production and livestock) in western Sudan;

2) Review the general characteristics and causes of food insecurity in western Sudan;

3) Review the current activities against food insecurity in western Sudan;

4) Develop different policy recommendations in order to improve the current level of farming system and food security in western Sudan.

\section{Research Methodology}

\subsection{The Study Area}

North Kordofan State is located in the Western part of Sudan between latitudes $12^{\circ} 15^{\prime} \mathrm{N}-16^{\circ} 32^{\prime} \mathrm{N}$ and longitudes $27^{\circ} \mathrm{E}-32^{\circ} \mathrm{E}$. The total area of the state is equivalent to $224,700 \mathrm{~km}^{2}$. According to the administrative governmental system in Sudan; the new North Kordofan State is composed of nine localities: Sheikan, Bara, UmRuwaba, Gabrat El Sheikh, Sodari, El Nuhoud, Gebash, Wad Banda, and Abu Zabad, of which four of them were merged from the former West Kordofan State. The total number of localities consists of approximately 33 administrative units [8]. Figure 1 shows the map of North Kordofan State.

The population of the state has been estimated about 2920.99 inhabitants based on the last census in 2008 [9]. Thus, due to the better standard of living conditions, a higher density of the population is concentrated mainly in the bigger localities of Um-Ruwaba, Sheikan, and Bara in contrast to the other localities. The majority of the population (79\%) relies on the traditional farming agricultural system, and their activities contribute to the household's food security and rural development [8]. Poor households in terms of owning few assets are characterized by high vulnerability and represented about $30 \%$ of the total households [10]. The majority of the rural communities depend on activities that are based mainly on the utilization of natural resources such as traditional crop production, raising of livestock, gum Arabic tapping, and seasonal labor migration.

\subsection{Data Collection and Analysis}

The study was based mainly on the secondary data. The secondary data was used to collect the relevant information that related to the cropping patterns, cultivated area under food and cash crops, crop production (cash and food crops), rainfall condition, numbers of livestock, food consumption pattern and causes of food insecurity. The data was collected from different sources such as ministry of agriculture, ministry of animal wealth, ministry of health, WFP, FAO in addition to the other relevant publications.

Descriptive statistics analysis was used to analyze the secondary data. Averages, percentages histograms were applied to disclose the cropping pattern, cultivated area, crop production, rainfall, number of livestock, food consumption gap as well as the activities against food insecurity. The data was analysed using SPSS software (version 20).

\section{Results and Discussions}

\subsection{Traditional Farming System}

The traditional farming system in North Kordofan State can be determined by the degree of settlement, the emphasis on crop cultivation, and raising of livestock. The crop production is basically traditional rain fed farming system. It is composed of small holdings in which different crops are cultivated for the purpose of subsistence and export. This is a typical model of low agricultural input. In this farming system, large-scale irrigation is absent; use of fertilizers, pesticides, and weed control are also limited. Soil management does not require mechanized tool techniques and equipments [12]. 


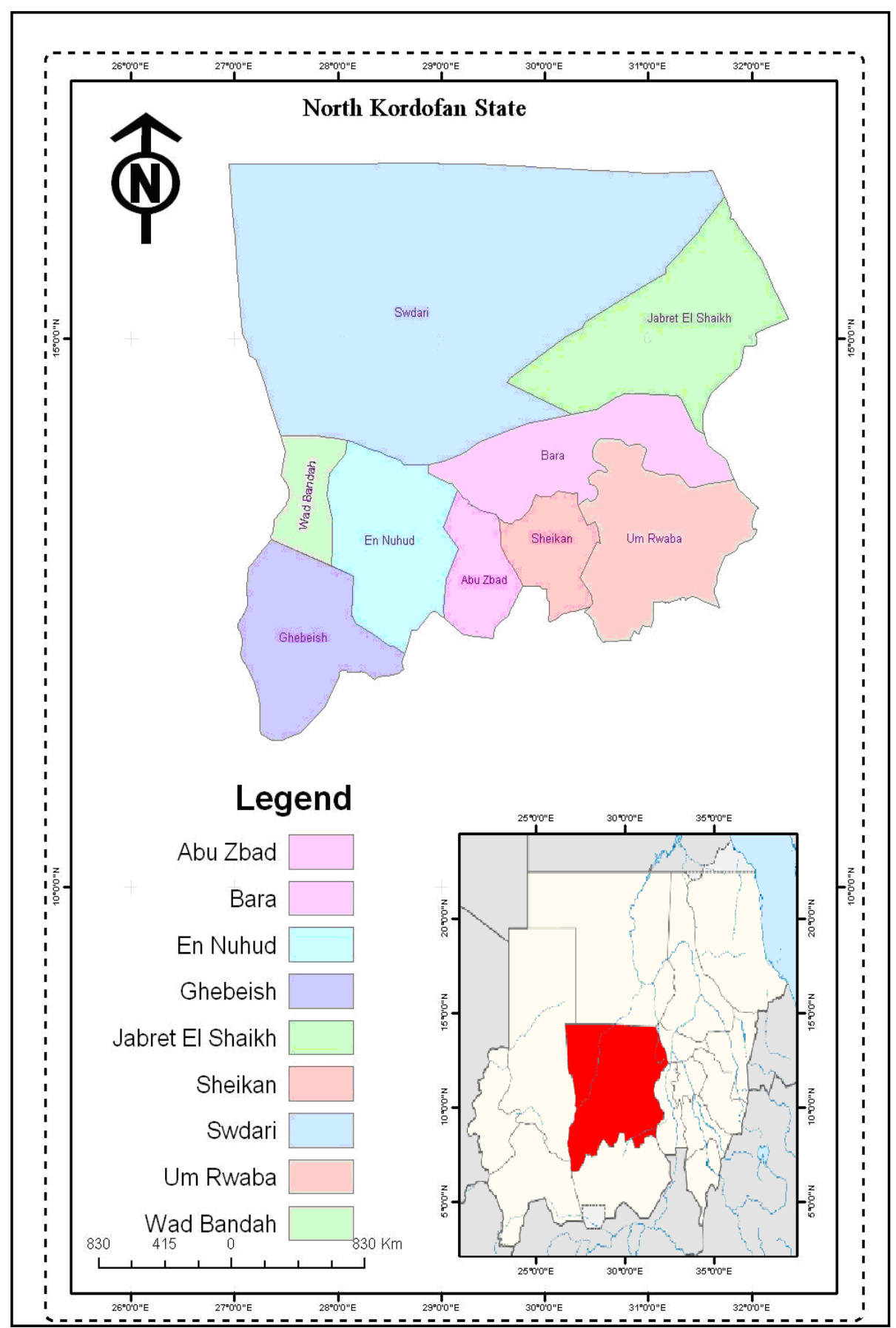

Figure 1. Map of the study area [11].

\subsubsection{Cropping Pattern System}

The cropping patterns in the western Sudan have changed gradually over the time. These changes are based on the variation of the environmental conditions and government agricultural policies. The current situation of the western Sudan is reflected the impact of government policies. In the beginning of the second half of the 1960s, these policies favored the expansion of cash crops, particularly oil seed crops (sesame and groundnut). The consequences of the government agricultural policies caused an unexpected transformation of crop production patterns from subsistence to commercial farming. In that time, small farmers were not obligated to reduce their normal cultivation of food crops; they were encouraged to increase the cultivation of cash crops [2]. This policy 
was chiefly motivated by a high export value of cash crops through the adoption of loan conditions from the Agricultural Bank of Sudan (ABS). The commercial banks also played an important role in promoting the unbalanced production of field crops by adopting this market oriented strategy. Additionally, the government agricultural policies disrupted the market system. The price policy for cash crops was either declared later or set below the international market price. The grain prices were always set below the market levels even when the ABS and/or the government made the purchases. In many cases the farmers were the losers. Accordingly, the traditional farmers were faced with lack of credit, marketing difficulties, higher costs of agriculture, high costs of livestock inputs, as well as the household goods. To achieve food security and to reduce the income gap, the farmer is inevitably pushed to harvest more from the land. More land is planted to compensate the risks of crop production failure, which results in recurrent droughts and pest eruptions before the harvest. This leads to the misuse of land and natural resources [12].

In the past decades, the small-scale farmers cultivated food crops with limited amounts of cash crops for the market. The recurrent drought and desertification have raised the hazard of agricultural production due to higher variability and instability in rainfall conditions. This has had a hard impact on the small holder farmers in the western Sudan. Accordingly, they shift their cropping patterns by cultivating more food crops in order to secure sufficient food grain for their families and for the market as well. This happens during years of good agricultural seasons when there is more rainfall in terms of quantity and distribution. In this situation the farmers could store a part of their grain production in order to consume it during the bad seasons. Subsequently, rural people in the western Sudan did not experience any food grain gaps until the mid-1970s [2] and [3]. Recently, small-scale farmers have had a tendency to produce more cash crops than food crops. Thus, their status has been changed from subsistence peasant farmers to commercial farmers. The oil seed crops of sesame and groundnuts are the most important cash crops. There has also been expansion in the production of minor field crops such as hibiscus "Rosella" and watermelon seeds. Moreover, besides the cultivation of field crops, gum Arabic is broadly produced in this region. It contributes about 50\% to Sudan's GNP [8]. The recent change in the cropping pattern system has influenced the yield of crops, food prices, and market conditions as well.

\subsubsection{Rainfall Condition}

The level of rainfall has been declining and fluctuating from one year to another during the past three decades in Sudan. In the arid and semi-arid zones of western Sudan the agricultural activities depend greatly on rainfall. However, rainfall in the Western region of Sudan is characterized by a short season and is highly changeable in its trends. The mean annual rainfall as one move from north to south ranges from almost zero in the Northern States to more than $1400 \mathrm{~mm}$ in the Southern and Western parts of the country [6]. The statistical meteorological data reveals that there is approximately one year in every three years in which the average rainfall falls below the actual mean [13]. Thus, higher variability and declining rainfall had substantially damaged the food entitlements and food consumption for a large segment of the population through the fluctuations in crop production, low income and low productivity of labor [3].

North Kordofan State is in the tropical zone which is characterized by short rainfall season. The rainfall season extends from June or July to September and reaches its peak in August. However, the meteorological data show a wide variation in the rainfall from year to year as illustrated in Figure 2. It clearly shows higher variation in rainfall $(\mathrm{mm})$ from 1997 to 2012. Generally, the average rainfall ranges between $484 \mathrm{~mm}$ to $1333.3 \mathrm{~mm}$. The rainfall also shows higher variation among the years. The higher fluctuation and variation in rainfall emerged from serious desertification and drought during the last two decades. Rainfall is an important factor that puts great pressure on the crop production and pastoral system. Consequently, the amount and distribution of rainfall among the region is the key determinant for the performance of the agricultural season and crop output. Thus, variability of rainfall has always played a major role in production shortfalls. This has often been associated with food insecurity problems.

\subsubsection{Cultivation of Food and Cash Crops}

Crop cultivation is the major activity for the rural population. In general, the practice of crop production follows the shift cultivation system of land. Normally, the land is cultivated for $4-6$ years, and then the farmer leaves the land fallow for 15 - 20 years in order to reinforce its fertility. Conversely, the shift cultivation period varies among the areas, rural communities, and farmers in the same village. Recently, the fallow periods have been decreasing, which indicates higher pressure on the soil as long as no fertilizers are applied to compensate for the 


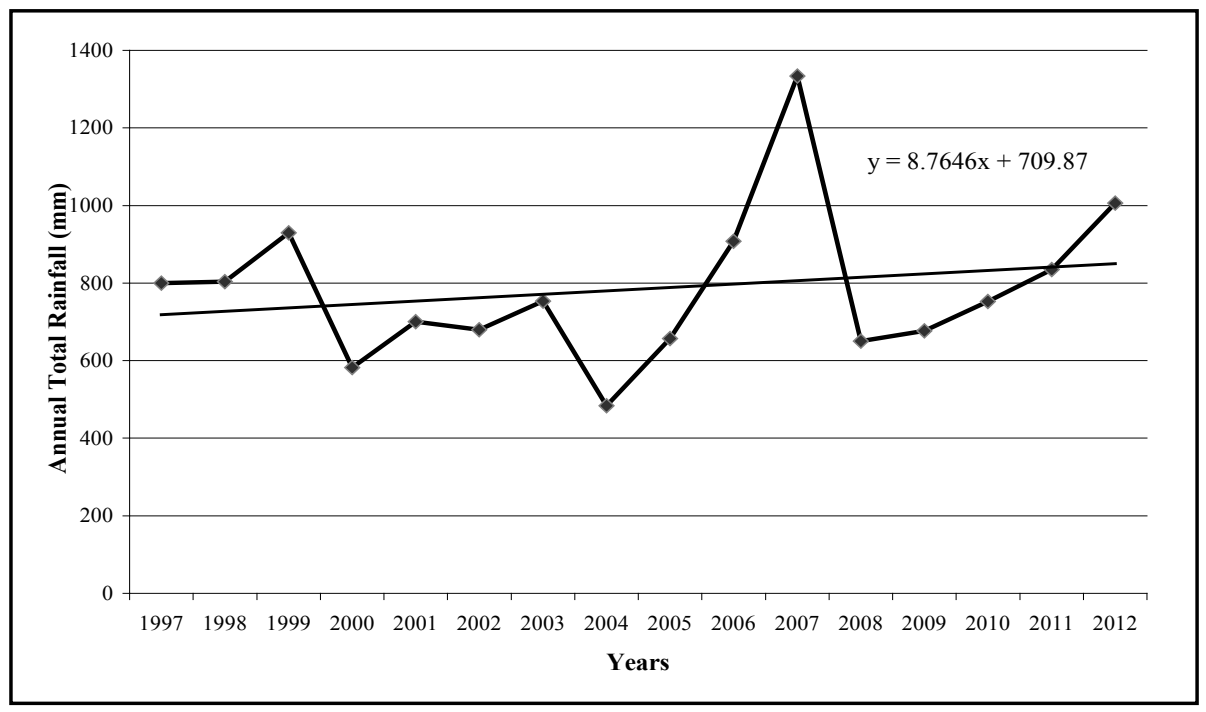

Figure 2. Average distribution of annual rainfall in North Kordofan State (1997-2012) [14].

loss of soil fertility in this region. This has generated two serious problems. First it is reduced the quality and quantity of crop output. Second it is produced fragmented and poor soil as a result of the misuse of land. Moreover, the soil in western Sudan had deteriorated and lost most of its potential with almost no recovery [12].

The reduction in food and cash crop productivity has perceptibly emerged from a general comparison of the average weighted yields for the major field crops over five ten-years periods as shown in Table 1. It appears from the table that the yield of sorghum was higher in compared to the yield of millet from period (1970/71$1979 / 80)$ to $(2010 / 11-2012 / 13)$. Additionally, the yield of groundnut was higher from period (1970/71-1979/80) up to (2010/11-2012/13) in compared to the yield of sesame. The table shows the higher fluctuation of all crops productivity over the five ten year's periods. Therefore, moving from high yield to low yield would reflect the low crop production in the traditional farming of western Sudan as a consequence of poor farm management and inappropriate policy strategies. The low productivity of crops is caused by a number of factors, among them low soil fertility, low and erratic rainfall, eruption of pests and diseases, and poor adoption of improved seed varieties.

Millet and sorghum (as subsistence food crops) are produced extensively by the farm households in the study area to cover their food subsistence needs. On the other hand, groundnut crop is grown in the western part of North Kordofan State, while sesame crop is cultivated in the Northern part. However, both crops are cultivated to provide cash income in order to satisfy other food and basic needs for the farmers. The analysis of the cultivated areas and production of both food and cash crops was revealed the vital role for these crops in food security. The time series data exposed the current trends of the average cultivated area by sorghum and millet crops in North Kordofan State from period 1970/71 to 2012/13 as illustrated in Figure 3.

The fluctuation in the cultivated area of sorghum and millet crops is explained by inadequate management of field crop practices and lack of technology adoption. The serious impact of environmental conditions such as desertification and drought contribute negatively to the cultivated area. In view of the fact that millet is a stable food for consumption, its production is characterized by large cultivated areas during the last 43 years relative to sorghum crops. Nevertheless, an analysis of the cultivated area would not reveal the complete picture on the performance of crops unless the production of these crops can be analyzed.

The analysis of production for both food crops (sorghum and millet) in North Kordofan State from season 1970/71 to 2012/13 as shown in Figure 4. The production of millet and sorghum crops recorded continuous declining and fluctuating during the period 1970/71-2012/13. Despite of an increase in the cultivated area of millet crops its production exhibited an acute decline. Millet is very sensitive to the instability of rainfall and drought. Thus, the fluctuation in the total production of both millet and sorghum often result in food insecurity, most of the time manifested in the form of localized or pockets of food insecurity.

An analysis of the cultivated areas by groundnut and sesame crops is exposed in Figure 5. The trends analysis showed the large increase in the cultivated area by cash crops. This outcome coincides with the objectives of the 
Table 1. Average yields (kg/fed) for the major crops over five ten-year periods from 1970/71-1979/80, 1980/81-1989/90, 1990/91-1999/2000, 2000/01-2009/10 and 2010/11-2012/13 in the North Kordofan State, Sudan [15].

\begin{tabular}{ccccc}
\hline Periods & Sorghum & Millet & Sesame & Groundnut \\
\hline $1970 / 71-1979 / 80$ & 123.5 & 73.7 & 53 & 134.4 \\
$1980 / 81-1989 / 90$ & 73.6 & 44.4 & 47.7 & 143.7 \\
$1990 / 91-1999 / 2000$ & 64.2 & 27.3 & 24.9 & 111.8 \\
$2000 / 01-2009 / 10$ & 97.1 & 53.9 & 51 & 183.4 \\
$2010 / 11-2012 / 13$ & 101.7 & 50.7 & 63 & 176.3 \\
\hline
\end{tabular}

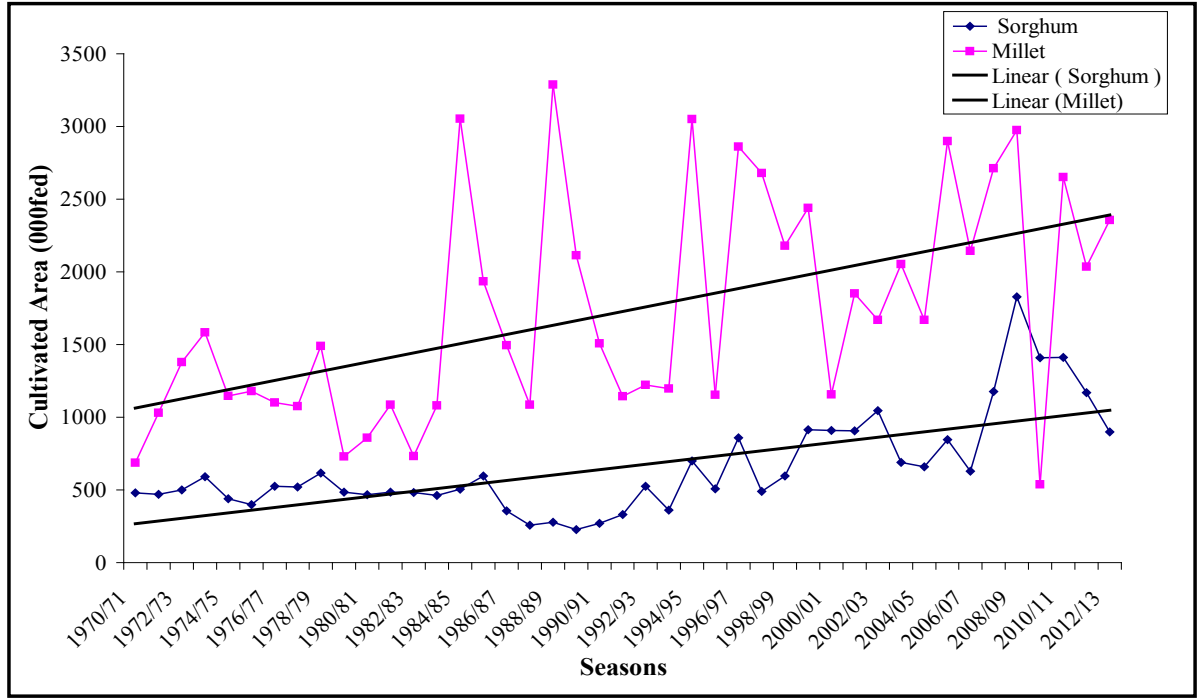

Figure 3. Average and trend of cultivated areas ( $000 \mathrm{fed}$ ) by food crops (sorghum and millet) in North Kordofan State during the period 1970/71-2012/13 [15].

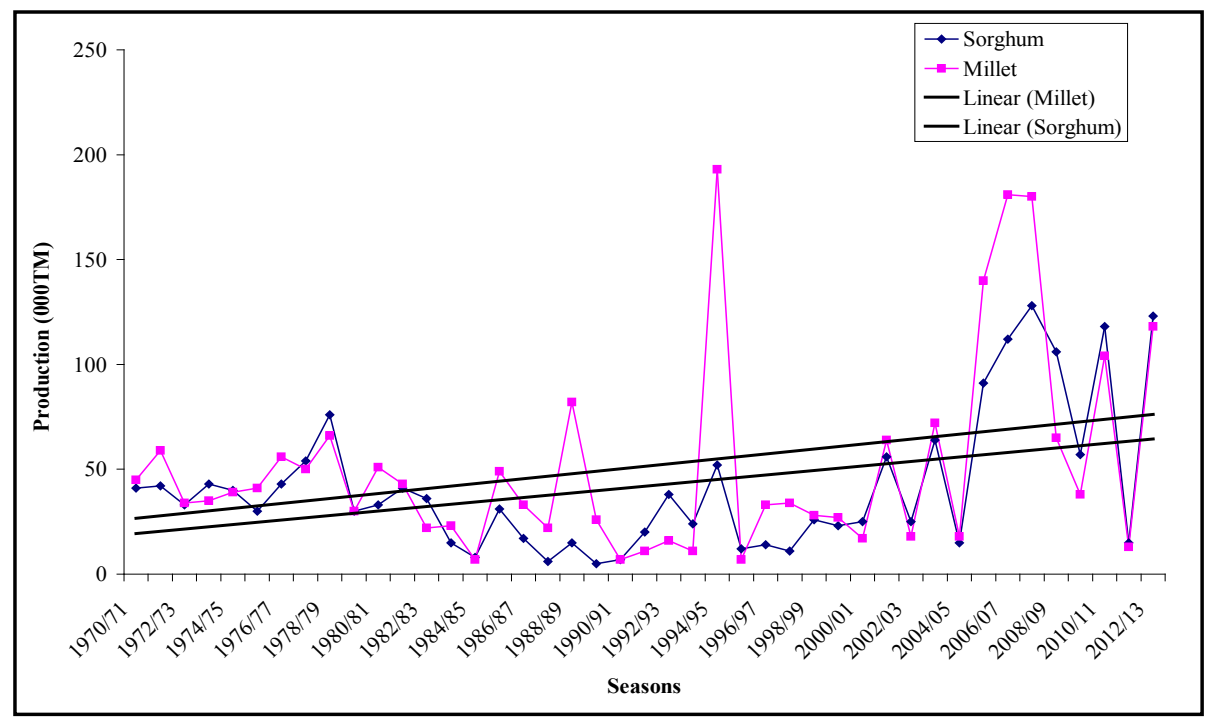

Figure 4. Average and trend of production (000TM) for food crops (sorghum and millet) in North Kordofan State during the period 1970/71-2012/13 [15].

government policies that seek to expand the cultivated area under cash crop production for the purpose of market orientation and export. Thus, the trends of the cultivated area by cash crops increased from 1970/71 to $2012 / 13$. This is described by upward trends in the cultivated areas for both groundnut and sesame. 


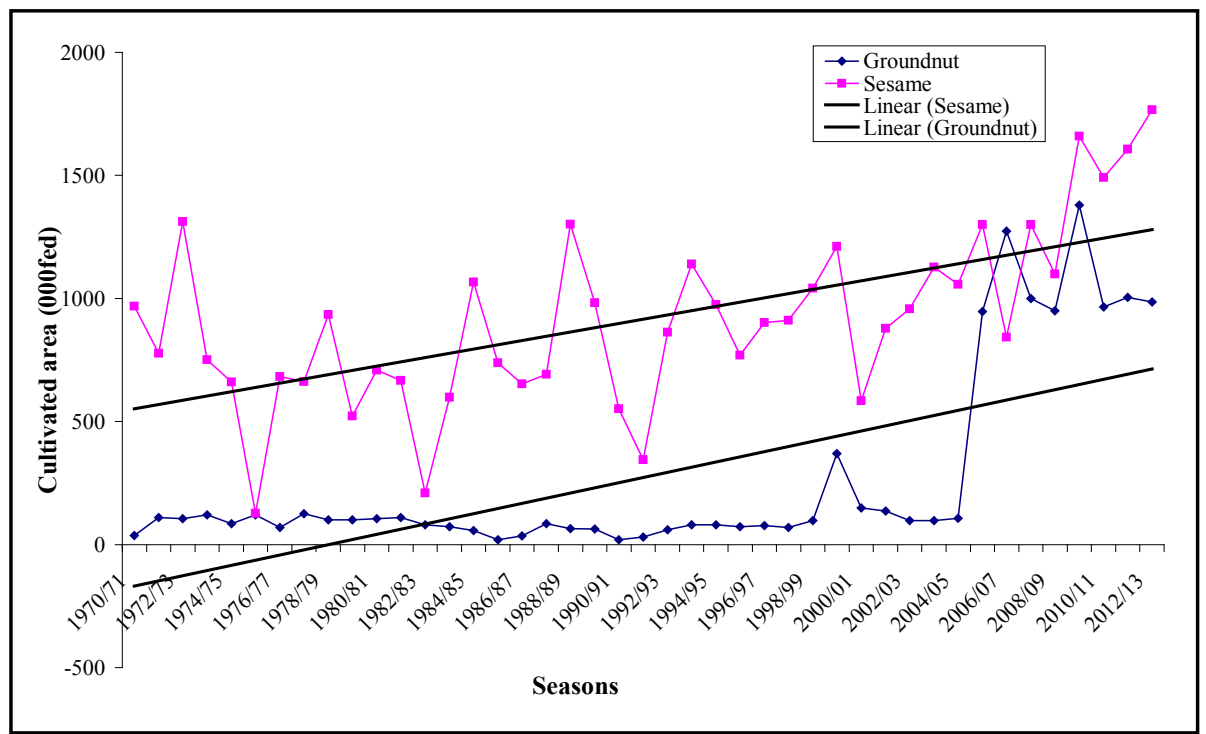

Figure 5. Average and trend of cultivated areas $(000 \mathrm{fed})$ by cash crops (groundnut and sesame) in North Kordofan State during the period 1970/71-2012/13 [15].

Furthermore, the time series data for analyzing the output of cash crops during the period 1970/71-2012/13 is clearly demonstrated in Figure 6. The figure shows the forward trend of groundnut production in compared to sesame production. Consequently, the output trends for both food and cash crops reflect the inadequate situation of food security in North Kordofan State, since cash crops are the most important farm income sources.

\subsubsection{Livestock System}

The western Sudan contributes significantly to the livestock production in Sudan. This region contains three important sub-systems of livestock. The nomadic sub-system is characterized by the migration of herds either cattle or camels. They migrate and move from the North to the South throughout the year, seeking good grazing and water points. They migrate to the south in the dry season when the rains stop and the areas are still favorable for better pastoral conditions. During the rainy season, herders migrate to the north when the conditions in the south become extremely wet coupled with the spread of insects and diseases. In this sub-farming system, no crop cultivation is practiced, and herders depend on the market to satisfy their consumption and other needs. Until recently, it was rare in the southern parts of North Kordofan State to have conflicts concerning the competition over the natural resources [16]. The second sub-system exhibits a similar directional movement of nomadic herders. The transhumant practice crop cultivation in specific areas along their direction of movement. In this case, part of the family members remains behind to take care of crop cultivation. The sedentary is the third subsystem, in which farmers settle in villages and practice the traditional system of crop cultivation and livestock raising as well as engage in off-farm activities [17].

Therefore, the most significant activity in North Kordofan State besides the cultivation of crops is grazing livestock. Good performance of livestock populations is determined by the amount of crop residues and the richness of the natural pasture system. The contribution of desert sheep to Sudan's GNP is estimated at about 70\% [8]. This reveals a possibility to improve and develop the pastoral system in western Sudan as it plays a vital role in Sudan's trade and export market.

The local herds in North Kordofan State consist of sheep (the most numerous), camels (the most valued), and goats, although the large cattle herds are not commonly owned by local pastoralists. Cattle herds are more important in South Kordofan State, and they move to North Kordofan State only during the rainy season (grazing settlements). The statistical data of livestock exhibited a disparity in the number of livestock in different localities in the state from 2003 to 2011 (see Figure 7). The figure shows the increase in the numbers of all livestock, from 2003 to 2006, albeit there was a huge reduction in the number of sheep from 2007 to 2011 compared with 2005 and 2006. The large numbers of livestock being raised in the North Kordofan State is attributed to the higher potential of the pastoral system. 


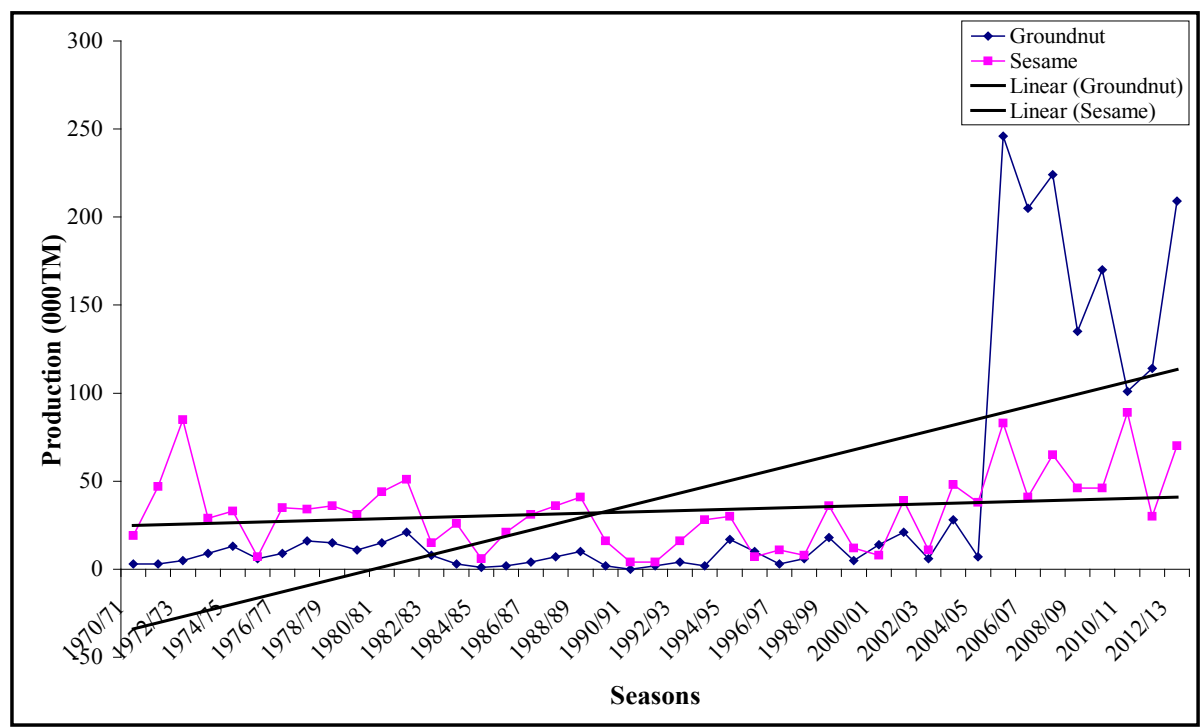

Figure 6. Average and trend of production (000TM) for cash crops (groundnut and sesame) in North Kordofan State during the period 1970/71-2012/13 [15].

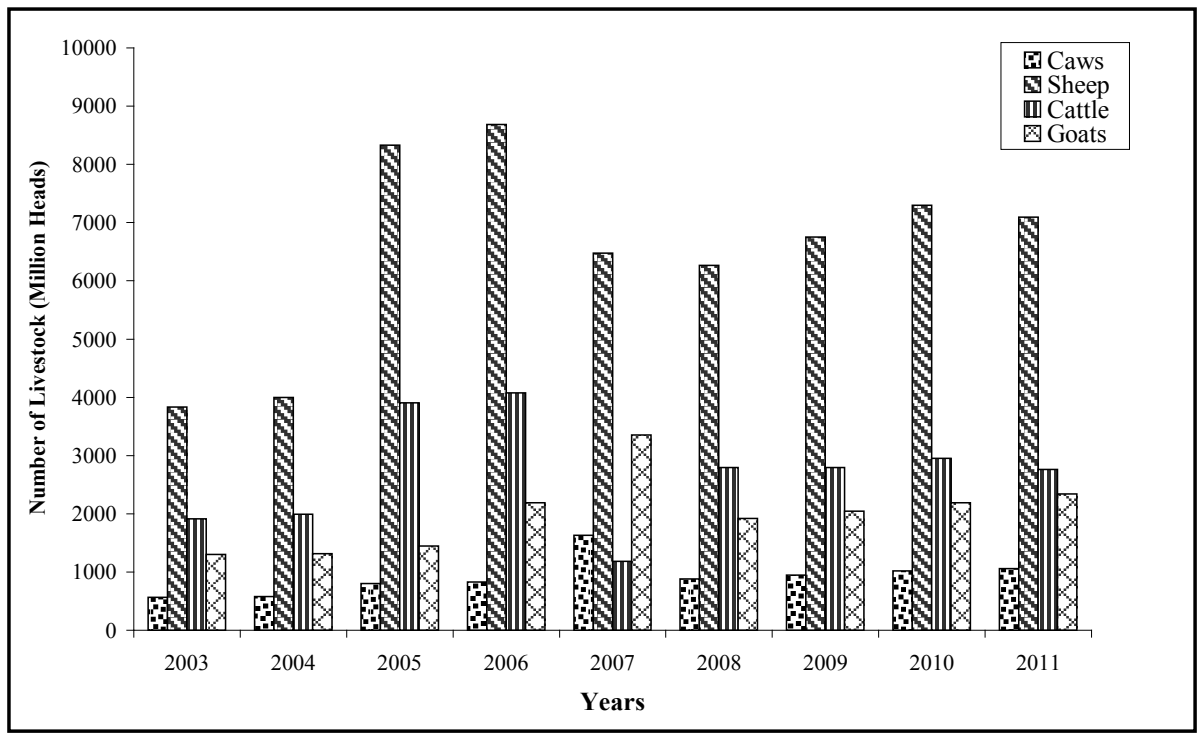

Figure 7. Number of livestock (million heads) in North Kordofan State (2003-2011) [18].

\subsection{Food Security}

\subsubsection{Food Consumption Pattern}

The food consumption pattern is symbolized as one of the important features of food and nutrition security for individuals and communities as well. The dominant local food for the majority of the population in Sudan as well as in North Kordofan State is cereal foods. The average food basket consists of cereal foods (millet or sorghum), pulses (cowpeas, lentils), oil crops (peanuts), meat, milk, dried okra, onions, vegetable oil, and sugar. In this context, Figure 8 shows the food consumption pattern and the share of different food groups in both rural and urban areas of North Kordofan State during the period 2002-2003. The consumption of cereal food in North Kordofan State is about $30 \%$ and $51 \%$ of the total food group consumed in urban and rural areas, respectively. The cereal foods contribute about $43 \%$ and $57 \%$ to the total daily per capita caloric intake in both urban and rural areas, respectively as reported by [19]. This was expected since most of the people in agricultural areas consumed what they usually produce on their farm. 


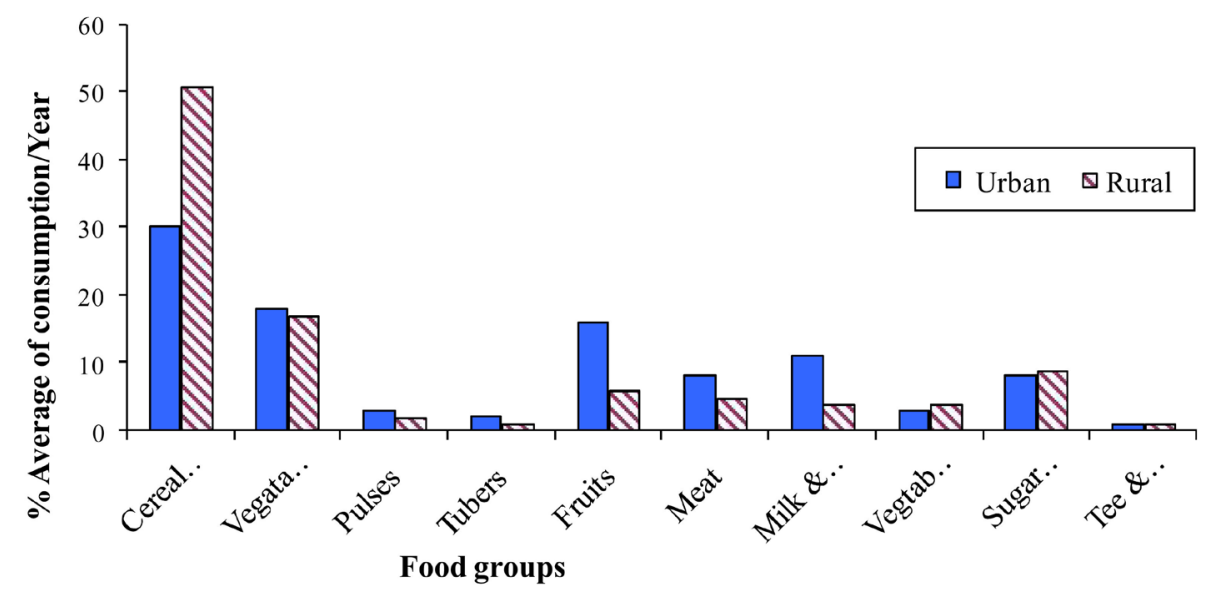

Figure 8. Average share of food consumption in both urban and rural areas of North Kordofan State in 2005 [19].

\subsubsection{Causes of Food Insecurity}

The western Sudan is well-known for its higher potential of natural resources. Yet, this area has experienced a higher deterioration in its natural resources due to drought that affecting the farming and pastoral system [3]. Besides decreasing the productivity of food crops, it emerges that the cereal foods of millet and sorghum characterized by higher prices in the local markets. The erratic rainfall and its greater variation in its distribution as well as poor storage capacity are also influenced the food security. The destruction of the environment and the spread of pests and diseases particularly during the storage process are distressing the crop output. The western Sudan is also suffered from low soil fertility, especially in sandy soil. This type of soil has a higher requirement for water, mainly in the production of millet crops. Meanwhile, negative impacts and the adjustment of liberalization policies that hit the rural areas hard also influenced access to food for the majority of the population. The marketing policy constitutes a concern for the farmers; therefore, a lack of clear marketing price policies for agriculture and animal production are also affected food security. This resulted in higher costs of production, which directly led to diminishing the net returns from different farming activities [20]. Moreover, the inequality and lack of income has a greater impact on the purchasing power of the people.

\subsubsection{Food Deficit}

North Kordofan State is recognized as a vulnerable food deficit area. The farmers and agro-pastoral herders are subjected to food insecurity since their agricultural production does not meet all their food consumption needs. The situation of food security is ever-changing and unpredictable among the seasons and usually depends on the amount of food and cash crops produced at the farm level. Cereal food production at the household level is one of the determinants of food availability. The trend of food security can be described through the percentage change between consumption and production of cereal food from season 1995/96 to 2006/07. Figure 9 views the surplus and/or deficit in cereal foods based on the amount of both production and consumption. The figure reveals that a higher food deficit has been occurring since the end of the last decade, when consumption exceeded production. This mostly emerged from a decrease in production as a consequence of poor soil fertility, inadequate rainfall, and drought. Therefore, the percentage change between consumption and production was negative. Only in season 2005/2006, there was a food surplus, which has been shown by the positive change between food consumption and production as shown in Figure 9. The sedentary farmers in North Kordofan State faced both shortage in food availability because of high fluctuations in the production due to unfavorable conditions and also severe inaccessibility to food because of acute, widespread poverty and limited off-farm income opportunities as reported by [12].

The food deficit that has been occurring year after year affected about $74 \%$ of the total population. This population mostly lived in the Sheikan locality, and they suffered from chronic food deficit. They were distributed as $64.6 \%$ and $82.3 \%$ in the Southern and Northern parts of the locality, respectively. In contrast, about $49 \%$ of the population in the state was regarded as food insecure in the year 2006 [20]. The average estimated food deficiency for food insecure households overall in the state was approximately $16.4 \%$. However, this figure varied 


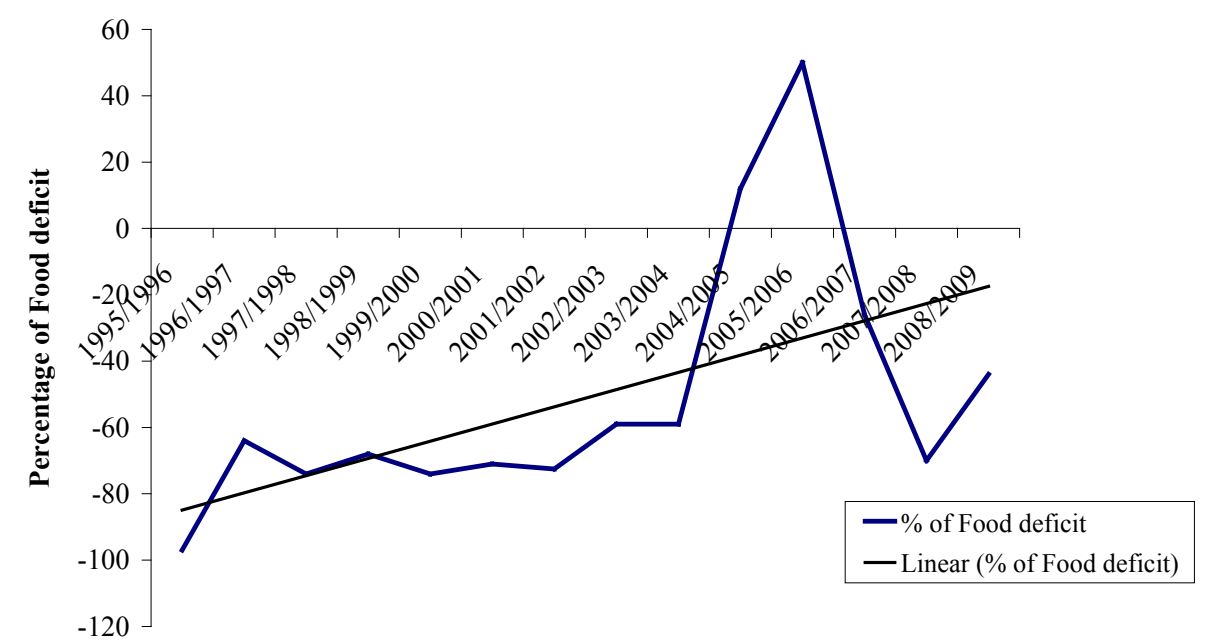

Seasons

Figure 9. Percentage of food deficit in North Kordofan State from 1995/96 to 2006/07 [22].

from $5 \%$ to $25 \%$ among the localities [21].

\subsection{Activities against Food Insecurity}

Various activities have been conducted in North Kordofan State to reduce the food gap and food insecurity. Many NGOs in the region were delivered relief food as free food distribution for the most vulnerable groups. This emergency food program seeks to secure food through food aid and relief during drought or bad seasons. This activity is usually conducted via coordination between governmental organizations (GOs) and non-governmental organizations (NGOs). Recently, there have been special programs implemented by the World Food Program (WFP) to improve the food insecurity situation. These programs are the School Feeding Program (SFP) and Food for Work (FFW). Unfortunately, despite the efforts made by these programs to alleviate food insecurity, there is only slight improvement. This is predominantly due to a lack of a good coordination between the government and international donors. Subsequently, many programs targeting the reduction of food insecurity have not successfully achieved their objectives.

\subsubsection{School Feeding Program (SFP)}

One of the most important activities for realizing food security in North Kordofan State is School Feeding Program (SFP). This program was implemented via an agreement between government representatives by the State Ministry of Education (SMOE), School Feeding Department (SFD), and the WFP. The agreement defined the terms and conditions under which the SMOE and SFD would implement the food distribution on behalf of WFP. The parties have agreed to continue their working relationship with respect to emergency operations [23]. The feeding is based on the breakfast meal that covers all students in the basic and secondary schools. The food provided by the WFP consists of cereal, pulses, oil, sugar, and salt. The food provided in 2011/2012 was estimated to be 4,406,390 metric tons, which represents about (50\%) of the total estimated food required to cover the needs of students in all schools. Therefore, the contract signed between the partner's states that the government should have to complement the nutrient component of food introduced by WFP. The numbers of school beneficiaries from the SFP in all localities in the state were about 1151 (see Table 2). This program encouraged students to enroll in school and thus; helped the stability of education. It was also successful in solving the problem of hunger during a short period of time and hence improved the health and nutritional status of the pupils. Conversely, the number of the pupils increased in the schools so they could enjoy the breakfast meal, but the amount of food didn't increase to compensate for the increased in the number of students. Additionally, a lack of food diversification as well as incomplete the nutrition component of foods provided (only caloric based foods) coupled with a delay in receiving this foods due to poor transportations which is negatively affected the sustainability of this program. 
Table 2. School beneficiaries from SFP in all localities in North Kordofan State (2011/2012) [24].

\begin{tabular}{cccccc}
\hline Localities & Secondary (female) & Basic school (male) & Basic school (female) & Basic school mixed & Total \\
\hline Bara & 7 & 27 & 28 & 284 & 346 \\
Sodari & 3 & 9 & 9 & 54 & 105 \\
Jabrat Elsheikh & 1 & 5 & 5 & 58 & 69 \\
Um Ruwaba & 12 & 19 & 24 & 230 & 285 \\
El Nuhud & 2 & 2 & 2 & 136 & 142 \\
Abu Zabad & 7 & 18 & 12 & 67 & 110 \\
Wad Banda & 5 & 10 & 0 & 0 & 84 \\
Sheikan & 7 & 0 & 0 & 0 & 7 \\
Gabaish & 6 & 0 & 98 & 913 & 6 \\
Total & 50 & 90 & & & 1151 \\
\hline
\end{tabular}

Table 3. Total amount of food distributed and the number of beneficiaries from FFW in North Kordofan State during the period 2002-2012 [25].

\begin{tabular}{ccc}
\hline Years & Total amount of food distributed (metric tons) & Total number of beneficiaries (persons) \\
2002 & 56,655 & 1960 \\
2003 & 294,782 & 8903 \\
2004 & 95,444 & 855 \\
2005 & $4,869,272$ & 7457 \\
2006 & $1,330,645$ & 4355 \\
2007 & 973,065 & 3312 \\
2008 & $1,398,261$ & 37,025 \\
2009 & $1,401,555$ & 40,512 \\
2010 & $1,490,908$ & 38,769 \\
2011 & $1,520,232$ & 39,640 \\
2012 & $1,588,070$ & 39,204 \\
Total & $14,667,452$ & 221,992 \\
\hline
\end{tabular}

\subsubsection{Food for Work (FFW)}

Food for Work (FFW) is another program conducted through joint activities between government representatives of the State Ministry of Finance and National Economics, Ministry of Agriculture, Animal Wealth and Irrigation, Humanitarian Aid Commission (HAC), and the WFP. The major goals of this program is to reduce the food consumption gap, help the community capacity, build and provide elements for stability such as drinking water and employment opportunities. It is understandable from the name of the program that people can receive food corresponding to their level of work. The participants in this program could be male or female. The amount of food per person per day is about $3 \mathrm{~kg}, 250 \mathrm{~g}, 250 \mathrm{~g}, 150 \mathrm{~g}$ and $50 \mathrm{~g}$ from sorghum, pulses, sugar, oil, and salt, respectively. The statistical data shows that the total food distributed by the FFW increased with an increase in the number of beneficiaries from the program. The number of beneficiaries increased from 1960 persons in 2002 to 39,204 persons in 2012, while the amount of food also increased from 566.55 metric tons to $1,588,070$ metric tons during the same period (see Table 3). This indicates that FFW is partially succeeded in its goals.

\section{Conclusions and Recommendations}

This paper exposed the characteristics and features of farming system and food security in the western Sudan. The agriculture and pastoral system is the main occupation for the majority of population in the region. Low agricultural production as well as inadequate farming system has led farmers to be vulnerable and susceptible to food grain deficit. Unfavorable climatic conditions of drought and desertification and their consequences are the decisive factors that influence the crop production and food security in western Sudan. The recent government policies have a great impact on changing the farming system. Therefore, this condition has influenced the food security since the cropping pattern was changed from subsistent crops to commercial cropping pattern. Moreover, 
the situation has been aggravated by inappropriate government agricultural policies and unclear market price policies, which affect the purchasing power of the people and hence create a higher level of inequity among the population. The food relief assistant through SFP and FFW has a substantial impact on reducing food insecurity among the people. However, lack of good coordination between the government and the international donors hampers the efficiency of these programs. Consequently, food consumption gap and food insecurity are still the dominant troubles in North Kordofan State.

Thus, to improve the situation in the western Sudan, the government should support the farmers through strong and powerful research institutions and extension services. This is expected to assist the farmers especially in the adoption of improved technologies and create off-farm activities such as petty trade and handicrafts to boost the farmers' income. Increasing the farmers' income will facilitate the farming system and food security (i.e. farmers have more ability to purchase inputs and improve their food consumption). The government should also enact appropriate policy interventions to support agricultural production system. Additionally, it is necessary to enhance and develop food and nutrition security through supporting the special food programs SFP and FFW. Both SFP and FFW should provide diversified foods that are nutritional based rather than caloric based for the vulnerable people.

\section{References}

[1] WFP (2006) Interim Poverty Reduction Strategy Paper (2004-2006). Background Paper. Khartoum Food Aid Forum, Khartoum, 6-8 June 2006.

[2] Elamin, M.E., Musa, H. and Er Rahil, I. (2009) Reconciling the Trade-Offs between Domestic Demand and Export Market: The Case of Sudan Dry Land Agriculture. Published under the Book of Economics of the Resource Use and Farming Systems Development in the Middle East and EAST AFRICA. Margraf Publishers GmbH, Germany.

[3] Teklu, T., Braun, J. and Zaki, E. (1999) Drought and Famine Relationship in Sudan: Policy Implication. IFPRI Research Report 88.

[4] ECA (2007) Africa Review Report on Drought and Desertification. Fifth Meeting of the Africa Committee on Sustainable Development (ACSD-5)-Regional Implementation Meeting (RIM) for CSD-16, Addis Ababa, 22-25 October 2007, 3-8.

[5] Elbashier, A. and Hamid, F. (2008) The Role of Agriculture in Poverty Reduction and Food Security in the Sudan. An IFAD-Funded Study Draft Report Prepared for Ministry of Finance and National Economy.

[6] Faki, H., Nur, E.M. and Abdelfattah, A. (2009) Poverty Assessment and Mapping in Sudan, Final Draft Progress Report North Sudan. ARC \& ICARDA, Khartoum.

[7] Hashim, S.I. (2008) Poverty, Food Security and Malnutrition in an Urban and Rural Setting: Case Study the Former West Kordofan State. Unpublished Ph.D. Thesis, University of Khartoum, Khartoum.

[8] MFEP (2008) Marketing of Agricultural Products in North Kordofan: Current Situation and Future Prospects. Book Prepared by National Expert Team for the Ministry of Finance and Economic Planning in North Kordofan State.

[9] Central Bureau of Statistics (CBS) (2009) Details Table of the Fives Population Census, 2008. http://www.cbs.gov.sd/

[10] IFPRI (2007) Managing Conflict over Natural Resources in Greater Kordofan, Sudan: Some Recurrent Patterns and Governance Implications. IFPRI Discussion Paper 00711, August 2007. In: Sadler, M.J., Strain, J.J. and Caballero, B., Eds., Encyclopedia of Human Nutrition, Academic Press Ltd., London, 433-441. www.ifpri.org

[11] Ministry of Science \& Technology (2011) Map of North Kordofan State. Remote Sensing Centre, Khartoum.

[12] El-Dukheri, I., Oyiki, C.O., El Wakeel, A.S. and Mesaka, S.K. (2011) Review of the Food Security and Natural Resource Situation in Sudan. Drylands Coordination Group (DCG) Report No. 63, October 2011.

[13] Meriod, E.M. (1989) The Effects of Drought and Desertification on Range and Livestock as a Production System on Northern Sudan Province: The Case Study of Sodari. Master's Thesis, University of Khartoum, Khartoum.

[14] MOST (2013) Ministry of Science and Technology, Meteorological Authority, Average Annual Rainfall Data for Both Elobied \& El Nhoud Area, Sudan (2009).

[15] GAPAE (2005-2013) Time Series Data of Area Planted Harvested and Yield Data of the Main Food and Oil Crops by State and Mode of Irrigation Production. Volume 1, September 2006, Data from Seasons 2005/06-2012/13, Ministry of Agriculture and Forest, General Administration of Planning \& Agriculture Economics.

[16] UN (2006) Share the Land or Part the Nation: The Pastoral Land Tenure System in Sudan (STUDY 3). www.sd.undp.org

[17] Mohamed, A.E., Adam, A.E. and Ahmed, A. (2008) Food Security in Sudan: Policy and Strategies. Globalization, Tech- 
nology and Sustainable Development Book Series, Inderscience Enterprises Limited, Geneva.

[18] SMAW (2012) State Ministry of Agriculture, Animal Wealth and Irrigation, North Kordofan State. Series of Annual Reports on Livestock, 2008-2011.

[19] Agami, A., et al. (2005) Food Consumption \& Nutritional Situation in Northern Kordofan State (2002-2003). Ministry of Agriculture and Forest, Administration of Planning \& Agriculture Economics, April 2005.

[20] Albalaa, T.M.A. (2007) Policy of Agriculture to Secure Food-Ministry of Agriculture Natural Resource and Irrigation, North Kordofan State. October 2007-World Food Day.

[21] ANA (2006) Sudan Annual Need Assessments, Food Security Report Regional Overview and Recommendations-A Collaborative Report of WFP, FAO, NGOs, Government of Sudan and Government of Southern Sudan Counterparts, Report Compiled by WFP Sudan.

[22] SMOH (2009) Annual Health Report. Department of Nutrition, State Ministry of Health, North Kordofan State.

[23] Idries, N.I.M. (2007) The Contribution of Non Governmental Organizations in the Field of Language and Education: A Case Study of North Kordofan State. Unpublished Master's Thesis, Nile Valley University, Khartum.

[24] State Ministry of Education (SOME) (2012) Report on the Beneficiaries from School Feeding Program. School Feeding Department (SFD), North Kordofan State, Sudan.

[25] Ministry of Finance \& Economics - General Administration of Development Planning (2012) Report on Water Harvesting Structures and Supporting the Infrastructure by Food for Work. North Kordofan State, Sudan. 
Scientific Research Publishing (SCIRP) is one of the largest Open Access journal publishers. It is currently publishing more than 200 open access, online, peer-reviewed journals covering a wide range of academic disciplines. SCIRP serves the worldwide academic communities and contributes to the progress and application of science with its publication.

Other selected journals from SCIRP are listed as below. Submit your manuscript to us via either submit@scirp.org or Online Submission Portal.
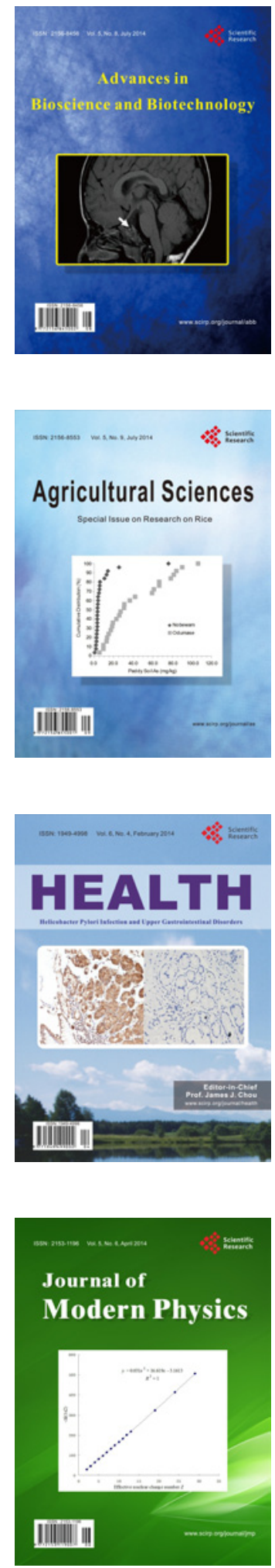
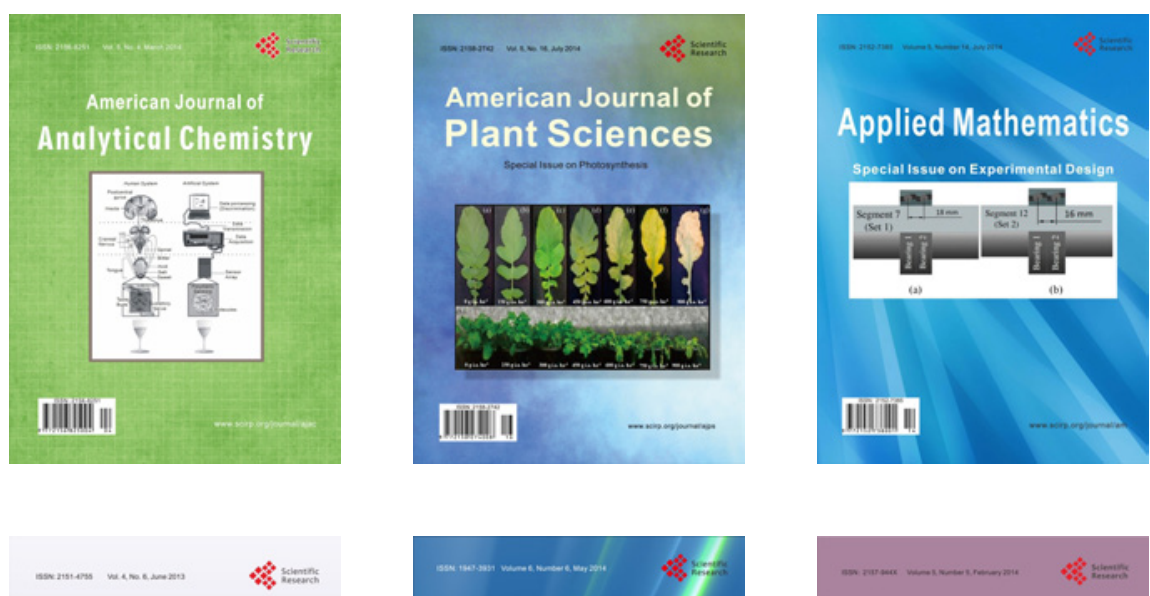

Creative Education
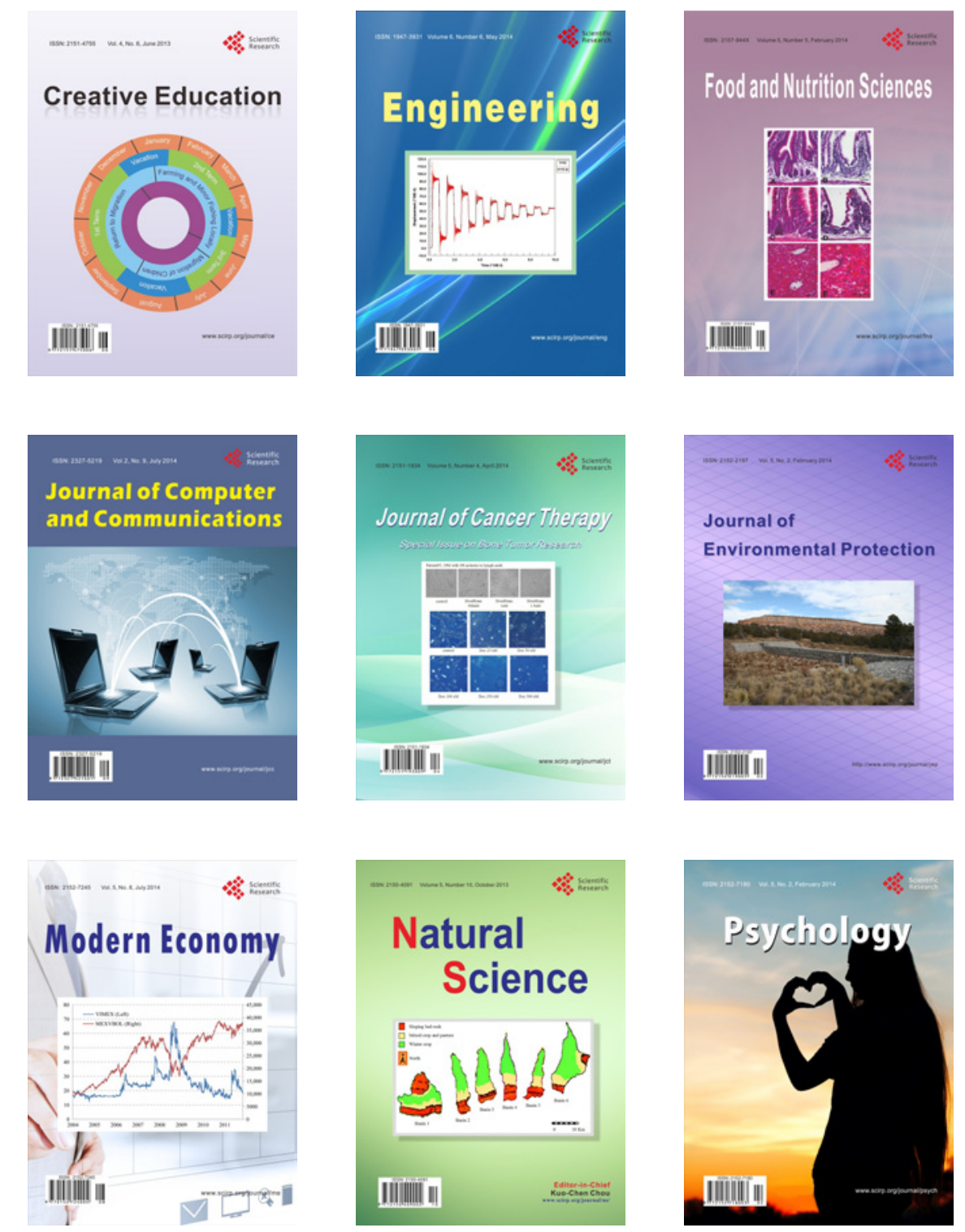